\title{
Volcaniclastic habitats for early life on Earth and Mars: A case study from $\sim 3.5$ Ga-old rocks from the Pilbara, Australia
}

\author{
Frances Westall $^{\mathrm{a}, *}$, Frédéric Foucher ${ }^{\mathrm{a}}$, Barbara Cavalazzi ${ }^{\mathrm{a}}$, Sjoukje T. de Vries ${ }^{\mathrm{b}}$, Wouter Nijman ${ }^{\mathrm{b}}$, \\ Victoria Pearson ${ }^{\mathrm{c}}$, Jon Watson ${ }^{\mathrm{c}}$, Alexander Verchovsky ${ }^{\mathrm{c}}$, Ian Wright ${ }^{\mathrm{c}}$, Jean-Noel Rouzaud ${ }^{\mathrm{d}}$, \\ Daniele Marchesini ${ }^{\mathrm{e}}$, Severine Anne ${ }^{\mathrm{f}}$ \\ a Centre de Biophysique Moléculaire, CNRS-OSUC, Rue Charles Sadron, 45071 Orléans, France \\ ${ }^{\mathrm{b}}$ Faculty of Geosciences, Utrecht University, Budapestlaan 4, 3584 CD Utrecht, The Netherlands \\ ' Planetary and Space Sciences Research Institute (PSSRI), The Open University, Walton Hall, Milton Keynes K7 6AA, UK \\ d Laboratoire de Géologie, Ecole Normale Supérieure, de Paris, 24, rue, Lhomond, 75231 Paris, Cedex 5, France \\ e via Torino 10, 40139 Bologna, Italy \\ ${ }^{\mathrm{f}}$ Department of Geological Sciences, University of Orléans, 45071 Orléans, Cedex 2, France
}

\section{A R T I C L E I N F O}

\section{Article history:}

Received 14 October 2009

Received in revised form

30 July 2010

Accepted 2 September 2010

Available online 15 September 2010

\section{Keywords:}

Early Archaean

Microfossils

Volcanic sediments

Pilbara

Mars

\begin{abstract}
A B S T R A C T
Within the context of present and future in situ missions to Mars to investigate its habitability and to search for traces of life, we studied the habitability and traces of past life in $\sim 3.5$ Ga-old volcanic sands deposited in littoral environments an analogue to Noachian environments on Mars. The environmental conditions on Noachian Mars (4.1-3.7 Ga) and the Early Archaean (4.0-3.3 Ga) Earth were, in many respects, similar: presence of liquid water, dense $\mathrm{CO}_{2}$ atmosphere, availability of carbon and bioessential elements, and availability of energy. For this reason, information contained in Early Archaean terrestrial rocks concerning habitable conditions (on a microbial scale) and traces of past life are of relevance in defining strategies to be used to identify past habitats and past life on Mars.

One such example is the 3.446 Ga-old Kitty's Gap Chert in the Pilbara Craton, NW. Australia. This formation consists of volcanic sediments deposited in a coastal mudflat environment and is thus a relevant analogue for sediments deposited in shallow water environments on Noachian Mars. Two main types of habitat are represented, a volcanic (lithic) habitat and planar stabilized sediment surfaces in sunlit shallow waters. The sediments hosted small $(<1 \mu \mathrm{m}$ in size) microorganisms that formed colonies on volcanic particle surfaces and in pore waters within the volcanic sediments, as well as biofilms on stabilised sediment surfaces. The microorganisms included coccoids, filaments and rare rodshaped organisms associated with microbial polymer (EPS). The preserved microbial community was apparently dominated by chemotrophic organisms but some locally transported filaments and filamentous mat fragments indicate that possibly photosynthetic mats formed nearby. Both microorganisms and sediments were silicified during very early diagenesis.

There are no macroscopic traces of fossilised life in these volcanic sediments and sophisticated instrumentation and specialized sample preparation techniques are required to establish the biogenicity and syngenicity of the traces of past life. The fact that the traces of life are cryptic, and the necessity of using sophisticated instrumentation, reinforces the challenges and difficulties of in situ robotic missions to identify past life on Mars. We therefore recommend the return of samples from Mars to Earth for a definitive search for traces of life.
\end{abstract}

(c) 2010 Elsevier Ltd. All rights reserved.

\section{Introduction}

\subsection{Early Earth and early Mars}

Rocks recording habitable conditions on the early Earth, as well as traces of early life, are of particular relevance for

\footnotetext{
* Corresponding author. Tel.: +33 238 257912; fax:+33 238631517.

E-mail address: frances.westall@cnrs-orleans.fr (F. Westall).
}

investigations of habitability on early Mars and for the search for past traces of life because environmental parameters on the two planets during their early histories were, in many respects, similar (McKay and Stoker, 1989; Jakosky et al., 2007; Westall, 2005a, 2008). The basic criteria for habitable conditions (related to carbon-based life, as we know it) are the presence of liquid water, the availability of organic carbon and biologically essential elements $(\mathrm{H}, \mathrm{N}, \mathrm{O}, \mathrm{P}, \mathrm{S}$, as well as trace amounts of transition metals), and the availability of energy (Nisbet et al., 2007; Southam et al., 2007a). 
Liquid water is essential for life-it provides a medium for chemical exchange without which life would not be able to appear (Brack, 2002). On Mars there is overwhelming geomorphological and geochemical evidence from the recent orbital and in situ missions for a significant amount of water during the Noachian period (4.1-3.7 Ga) (Bibring et al., 2006; Carr, 2006; Carr and Head, 2010) (after about 3.7 Ga climatic conditions on Mars deteriorated and the presence of water appears to have been more episodic (Bibring et al., 2006; Carr, 2006; Carr and Head, 2010). Although Mars did not have a global ocean as did the early Earth, there is evidence during the Noachian for a large ocean in the Northern hemisphere (e.g. Perron et al., 2007; Ruiz et al., 2004) and for large bodies of standing water in impact and volcanic craters (Cabrol and Grin, 1999; Carr, 2006; Heisinger and Head, 2002). The presence of a large amount of water on the planets' surface requires a relatively dense atmosphere, most likely consisting of primarily $\mathrm{CO}_{2}$ (Jakosky and Phillips, 2001) with admixed greenhouse gases, such as methane, water vapour, sulphur gases, and other compounds, whereas oxygen contents were extremely low (Kasting and Ono, 2006).

Given the volcanic nature of the Martian crust, the sediments deposited in these bodies of water and around their edges would have been largely volcanic in origin. Owing to the high heat flow from the mantle during its early history (Spohn, 1991), hydrothermal environments (Bishop et al., 2008) associated with volcanics and impacts would also have been common, as on the early Earth (Hofmann and Bohlar, 2007).

As an ingredient of life, carbon probably originated from both extraterrestrial and in situ sources. Carbon molecules were formed in the solar nebula and delivered to Earth by meteorites, micrometeorites, and comets (Mullie and Reisse, 1987; Cronin and Chang, 1993; Duprat et al., 2010). Relatively large amounts of carbon are also produced in hydrothermal systems (Holm and Andersson, 1998; Martin and Russell, 2007). Thus, carbon molecules were abundantly available on the primitive planets. The biologically essential elements, $\mathrm{H}, \mathrm{N}, \mathrm{O}, \mathrm{P}, \mathrm{S}$, and the transition metals would have been also abundantly available in the volcanic rocks, minerals and volatiles on both planets (Nisbet et al., 2007).

Finally, life needs a source of energy. Chemical energy is provided in the form of thermodynamic disequilibria between chemical species in close proximity, such as reduction-oxidation (redox) contrasts. For example, reduction of ferric oxides in hot lava in contact with seawater produces hydrogen, a common electron donor for primitive microbial life (Nisbet et al., 2007; Southam et al., 2007b). Solar photons are a more effective source of energy but the biological mechanisms needed to capture this energy (photosynthesis) are relatively sophisticated and most likely developed at a later stage (at least on Earth) after the initial appearance of cellular life.

Both planets in their early histories thus satisfied the criteria for habitability. Their environmental conditions were also largely similar from a microbiological perspective, i.e. on small spatial and temporal scales. Thus, after life appeared on the planet, an environment that is only ephemerally habitable has the potential of being colonised and inhabited.

Therefore, as a result of the similarities between the habitable environments on early Earth and early Mars, the Early Archaean sediments and the fossil biota they contain can be considered as relevant analogues for the study of potential Noachian habitats and life. In this contribution, we therefore present a comprehensive study of a shallow water volcano-sedimentary habitat and the traces of life that the sediments contained. The example we use is the 3.446 Ga-old "Kitty's Gap Chert" formation in the Coppin Gap greenstone belt of the Pilbara. It consists of silicified volcanic sediments deposited in a tidal/mudflat environment (de Vries, 2004; de Vries et al., 2006; Westall et al., 2006a) (Fig. 1). The sediments contain cryptic (microscopic and optically invisible) traces of life directly related to specific volcanic habitats: volcanic particle surfaces, pore spaces in volcanic sediments, and sediment surfaces. A preliminary description of the biosignatures was made by Westall et al. (2006a). The cryptic nature of the biosignatures necessitated the use of multidisciplinary techniques to be identified and interpreted. The investigative techniques used are highly relevant for establishing the biogenicity of potential biological remains in ancient rocks on Mars.

Subaqueous volcaniclastic sediments on the early Earth were suitable habitats for microbial organisms, such as chemotrophs, because they are a source of bio-essential elements and because the redox reactions at their surfaces were a source of energy (Furnes et al., 2004; Nisbet et al., 2007; Southam et al., 2007a; Westall, 2005a, b, 2009). Other habitats on the early Earth included shallow water and littoral environments within the

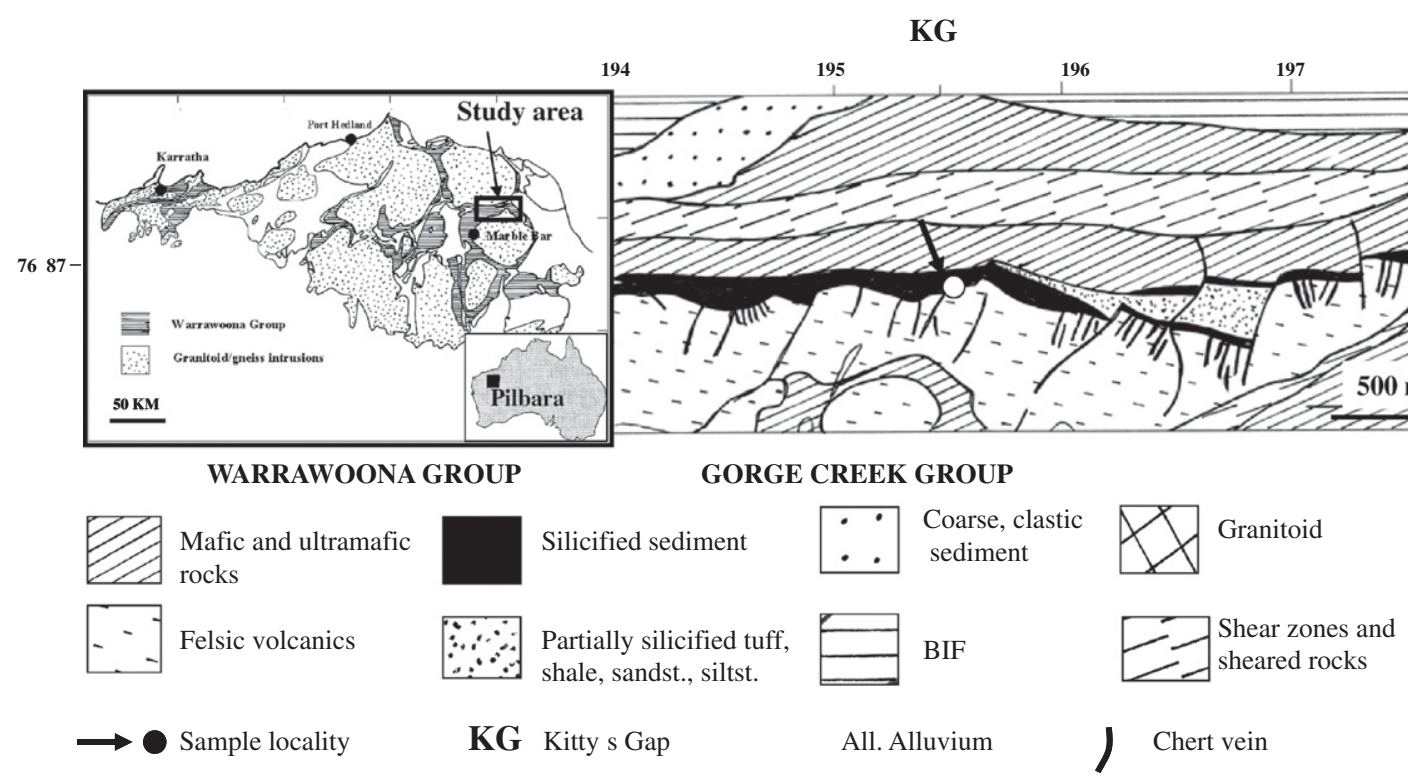

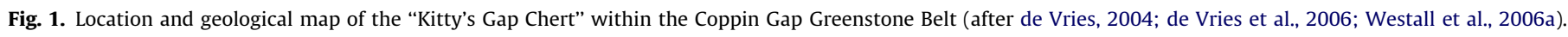



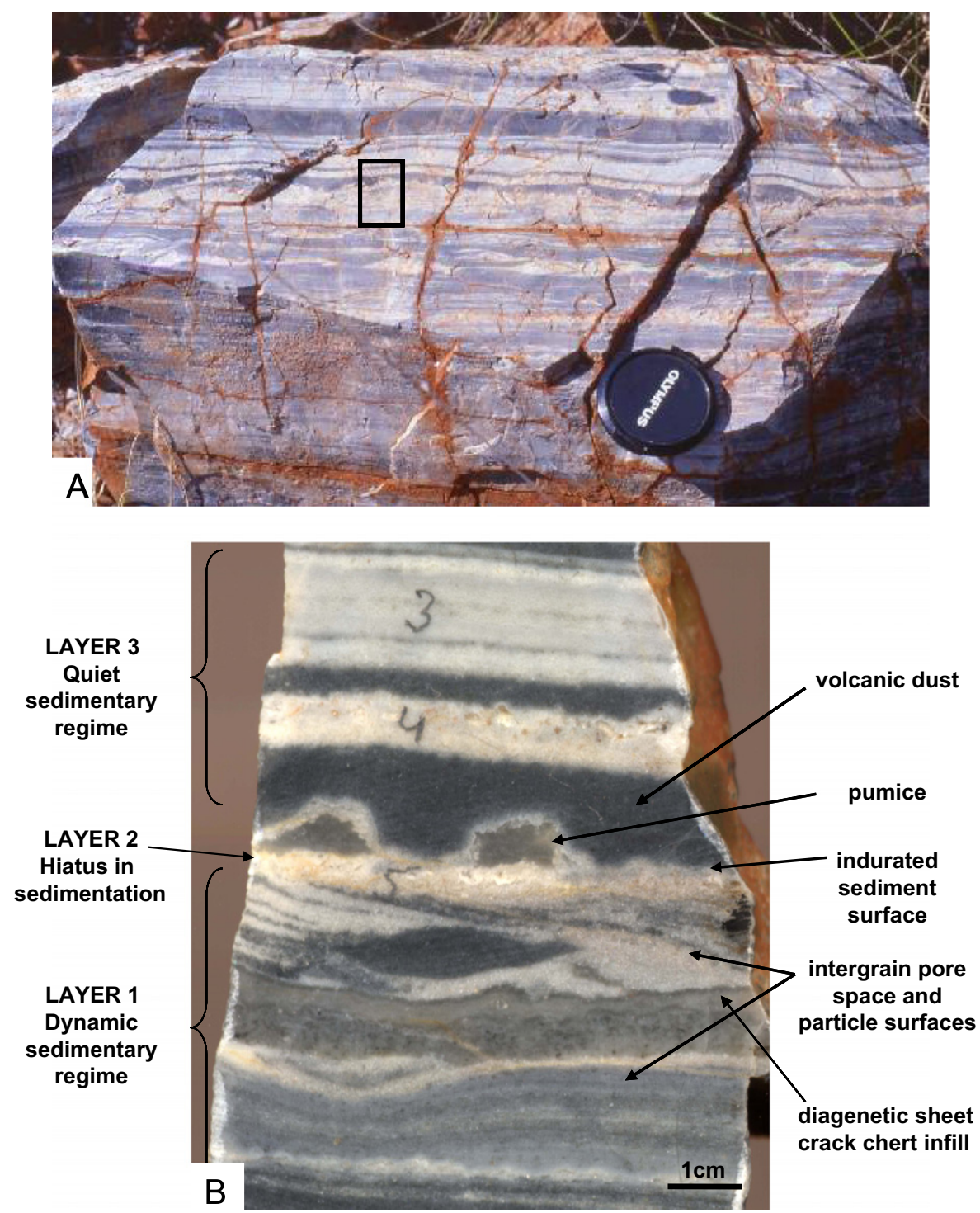

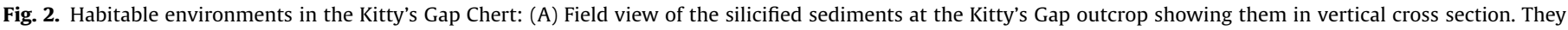

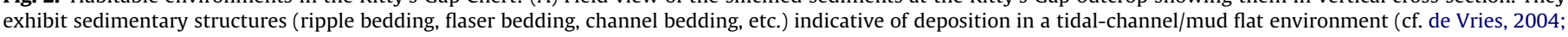

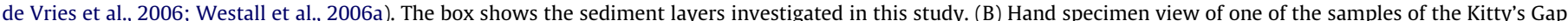

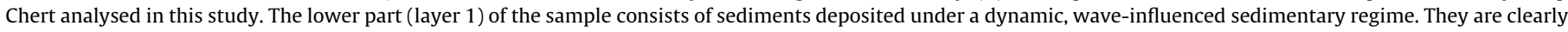

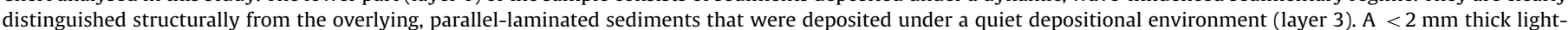

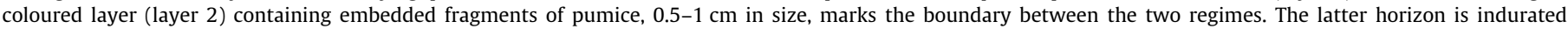

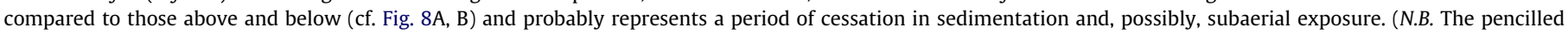
numbers $3-5$, on the sample have no relevance for this study).

photic zone (i.e. in water depths that could be penetrated by sunlight) that could have hosted photosynthetic microorganisms obtaining their energy from photons and forming microbial mats e.g. stromatolites (Southam et al., 2007b; Nisbet et al., 2007). Hydrothermal vents are also loci of much microbial diversity (Schrenk et al., 2003) and there is evidence of significant hydrothermal activity on the early Earth (Hofmann and Bohlar, 2007).

Preservation of the early terrestrial crust is extremely patchy owing to destruction or severe alteration by tectonic processes. Consequently, there are few locations on Earth where ancient sedimentary rocks are very well-preserved. The largest terranes are the Barberton greenstone belt in eastern South Africa and in the Pilbara craton in northwestern Australia. Both terranes are 3.5 billion (Ga) years old and younger but, for their great age, have undergone relatively low-grade metamorphism (upper prehnite- pumpellyite to lowermost greenschist). Extrusive and intrusive volcanic rocks and volcanically derived sediments (volcaniclastics) are the most widespread lithologies in these outcrops. The majority of the preserved sediments were deposited in shallow water/littoral environments (N.B. this does not mean that sediments were not deposited in the deep ocean, it is simply that deep water sediments prior to $3.3 \mathrm{Ga}$ have not been preserved).

\subsection{The Kitty's Gap Chert, 3.446 Ga, Pilbara, Australia}

\subsubsection{Geological context}

The 3.446 Ga Kitty's Gap Chert is part of the Coppin Gap greenstone belt in the Pilbara block, NW. Australia (Fig. 1). The sediments, deposited in a coastal mudflat/infilling tidal channel environment, overlie felsic and underlie ultramafic 

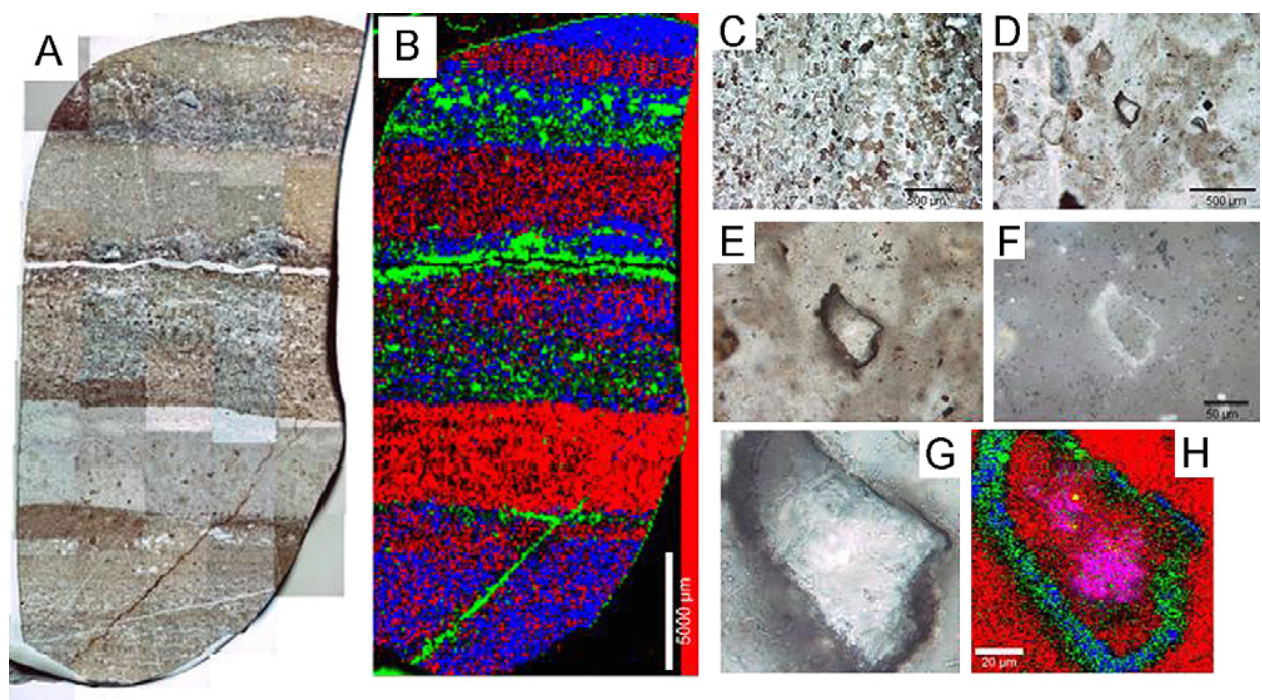

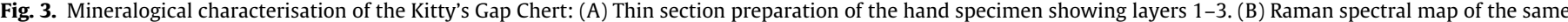

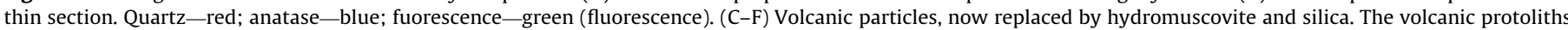

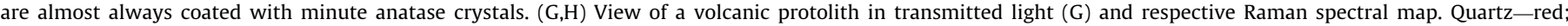
anatase-blue; kerogen_green; rutile-yellow; muscovite-pink. Note the association of kerogen with the surface of the protolith.

volcanics (de Vries, 2004; de Vries et al., 2006). The black and grey laminated sediments consist of millimetre to centimetre-thick layers of different grain size, the coarser sandy layers appearing grey to white, the finer silt to clay-sized materials appearing black (Fig. 2). Despite massive silicification of the volcanic sediments (Fig. 3B), their geochemical signature points to a felsic protolith (Orberger et al., 2006). During early diagenetic devitrification and alteration, the volcanic particles were replaced (pseudomorphed) by hydromuscovite (Orberger et al., 2006). Silicification of the sediments was more or less contemporaneous with their deposition, the silica coming largely from silica-saturated seawater as well as a minor local hydrothermal source (Orberger et al., 2006; van den Boorn et al., 2007; van den Boorn, 2008). The rocks underwent low grade metamorphism not exceeding uppermost prehnite-pumpellyite grade (H. Kisch, pers. comm., 2000).

\subsubsection{Habitability of the Kitty's Gap Chert}

We concentrated our sedimentological and biosignature study on a $\sim 10 \mathrm{~cm}$ vertical section of rock from the Kitty's Gap Chert (Fig. 2B). The lower half of the rock (layer 1 in Fig. 2B) consists of flat lying to gently rippled and graded sediments, indicating deposition in a low dynamic hydrological regime, typical of tidal sediments (cf. de Vries, 2004; de Vries et al., 2006). It is topped by a thin cream-coloured layer (layer 2 in Fig. 2B), 1-2 mm in thickness, in which $0.5-1 \mathrm{~cm}$ sized angular fragments of pumice are embedded. There is textural evidence that the white layer is an indurated horizon (cf. Fig. 9B), representing a stablised sediment surface and therefore a small hiatus in sedimentation. The evidence for this is that it is more silicified than the overlying layer of very fine-grained volcanic detritus (suspension-settled clay-silt-sized ash termed "volcanic dust" in this study; layer 3 in Fig. 2B). Moreover, the lower parts of the pumice grains embedded in this layer are also more silicified than in the upper parts. The upper part of the hand specimen (layer 3 in Fig. 2B) consists of alternating layers of flat-lying fine and coarser materials deposited under a quiet hydrodynamic regime without tidal influence. These layers are probably suspension deposits from ash falls. Within this overall sedimentological context, the Kitty's Gap sediments present two main types of potential microbial habitats: (1) volcanic lithic environments and (2) a stabilised sediment surface (Fig. 2B). Lithic environments occur throughout the rock and include the surfaces of the individual volcanic particles making up the sediment (e.g. Fig. 4A) (cf. Furnes et al., 2004; McLoughlin et al., 2007; Westall et al., 2006a), the pores spaces between the particles and in the fine dust layers, and the cavities within the scoriaceous pumice fragments embedded in the indurated sedimentary horizon (layer 2). The lithic environments could have hosted chemotrophic organisms that obtain their carbon from $\mathrm{CO}_{2}$ in the seawater and their energy from reduction/oxidation of inorganic (mineral) or organic (dead biological) materials. The indurated sediment surface (layer 2) could have hosted microbial biofilms and mats during periods of short hiatuses in sedimentation (Westall and Southam, 2006).

\section{Methods}

Many of the methods used in this study and the preliminary analyses are detailed in Westall et al. (2006a). Owing to the importance of the techniques used to determine biogenicity of the microfossils, we briefly describe them here. For this study we have included new Raman imaging. We have also made a re-evaluation of the microfossil traces in the Kitty's gap sediments in terms of microbial-scale habitability.

Basic sedimentological and petrographic analyses were made on uncovered $30 \mu \mathrm{m}$ thick petrographic sections of the chert with an Olympus DX51 optical microscope equipped with an Olympus DP12 digital camera. Some thin sections were investigated using high resolution scanning electron microscopy (HR-SEM) in secondary and backscatter electron mode and analysed using electron dispersive X-ray spectroscopy (EDX). Both unetched and HF-etched thin sections surfaces were examined. Etching times and concentrations ranged from 30 to $60 \mathrm{~min}$ and from $1 \%$ to $5 \%$. A sawn surface of the chert was etched in the fumes of concentrated HF for 60 min and observed by HR-SEM. All etched samples were thoroughly rinsed in ultrapure water after corrosion, ovendried and coated with $4 \mathrm{~nm}$ of gold for HR-SEM observation. Two instruments were used for the SEM studies: a JEOL FEG SEM 6400 at the Johnson Space Center, Houston and a Hitachi FEG SEM S4200 at the University of Orléans. 

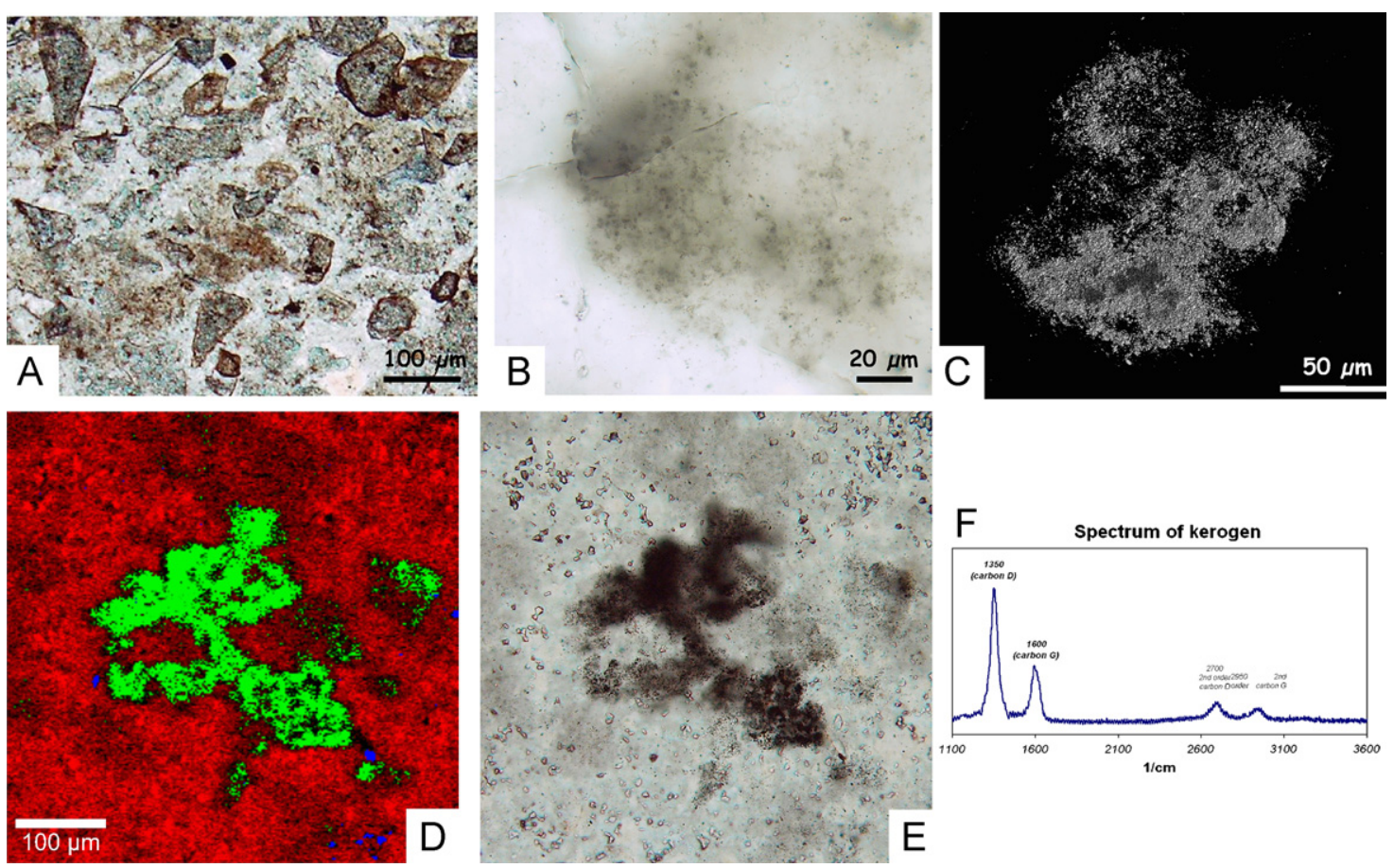

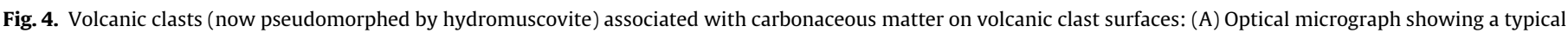

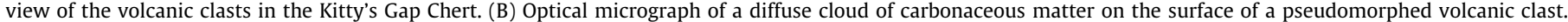

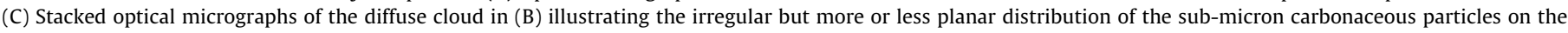

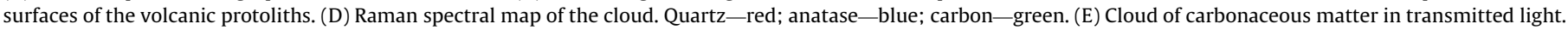
(F) In situ Raman spectrum of the carbonaceous matter in (E).

Bulk analyses of carbon and nitrogen concentrations and isotopic compositions were made on the extracted organic carbon of individual mm-thick layers of the sediment at the Open University by stepped combustion (from 200 to $1400{ }^{\circ} \mathrm{C}$ with 100 increment) using a static mode instrument MS-86 for the carbon (Wright et al., 1989; Verchovsky et al., 2002; see description in Westall et al., 2000) and a Finesse MS (Wright et al., 1988; Verchovsky et al., 1997). The system blank was $0.3 \mathrm{ng}$ of $\mathrm{N}$ and about $5 \mathrm{ng}$ of $\mathrm{C}$. The precision for $\delta^{15} \mathrm{~N}$ was about $\times 1.5 \%$.

High resolution TEM (HR-TEM) analysis of the kerogen was made on acid maceration residues with a Philips CM20 transmission electron microscope at the CNRS-Orléans. In situ SEM-EDS spot analyses and carbon maps were made of potential biogenic structures on etched surfaces. A Cameca SX50 Microprobe at the BRGM, Orléans, was used for major, minor and trace element analyses of individual volcanic particles. In situ Raman imaging and spectroscopy of specific carbonaceous structures at different levels within the $30 \mu \mathrm{m}$ thin sections was made with two instruments. We used a Dilor XY800 Raman spectrometer (ISTOCNRS-Orléans) with a green laser having a spectral resolution of $0.3 \mathrm{~cm}^{-1}$. The analytical spot size was $1 \mu \mathrm{m}$ diameter and penetrated to $\sim 2 \mu \mathrm{m}$ depth. The second instrument was a WITec 500RA atomic force microscope coupled with a confocal Raman spectrometer with a green laser ( $535 \mathrm{~nm}$ wavelength) having a spectral resolution of $3 \mathrm{~cm}^{-1}$ and a spot size of $350 \mathrm{~nm}$ (CBMCNRS-Orléans).

The 3.446 Ga-old sediments from Barberton and the Pilbara are the oldest rocks known that could contain well-preserved traces of life. In the study of these most ancient traces of life, two concepts are of critical importance, biogenicity, and syngenicity. Do the fossil traces originate from former life or life processes or are they abiological artefacts? If they are biogenic, were they formed at the same time as the rock or are they the signature of a younger intrusion of endolithic microorganisms? Interpretations of biogenicity and syngenicity of potential fossil microbial structures in the Early Archaean rocks is therefore of fundamental importance for understanding early life on Earth because it is the oldest record that exists. These two concepts are equally important in the search for past life on Mars. Although the primary emphasis for Mars will be on establishment of the biogenicity of the possible microbial chemical and morphological signatures, interpretations of the syngenicity of the structures will also play an important role in understanding the habitat and metabolic strategies of the Martian life forms.

For the purposes of this present study, the biogenicity and syngenicity of the chemical and morphological signatures were evaluated according to a series of previously established criteria (Buick, 1990; Cady et al., 2003; Schopf, 1993; Westall, 1999; Westall et al., 2006a; Westall and Southam; 2006). Biosignatures can be divided in three main categories (see review in Westall and Cavalazzi, in press):

(1) Physical structures, such as the remains of colonies, microbial mats, as well as structures produced by microorganisms, such as biolaminated sediments (including stromatolites), or textures produced in sediments, such as clotting. Note that microbes in colonies are often linked and embedded by a water-rich polymer film (extracellular polymeric substances, EPS), and microbial mats are always embedded by such a film. These polymers consist mainly of polysaccharides and have an extremely imporant function in microbial communities (Flemming et al., 2007; see also review in Westall et al., 2000). They protect the microbes in adverse conditions, aid attachment to substrates, and concentrate nutrients. They are permeated by channels that favour transport of nutrients into 
and transport of metabolites out of the mats. The polymers are often more readily fossilised than microbial cells because their open structure permits ready access of fluids saturated in dissolved mineral ions that fix to the numerous functional groups in their molecules (Westall et al., 2000).

(2) The chemical components of the cells/colonies/mats, i.e. the composition and structure of the organic molecules, including chirality.

(3) Expressions of the metabolisms of the microorganisms. These include fractionation of certain elements with preferential use of the lighter stable isotopes, e.g. C, S, N, Fe, by microorganisms; preferential concentration of elements e.g. $\mathrm{Ni}, \mathrm{Cu}, \mathrm{Mn}$, $\mathrm{Co}, \mathrm{Mo}, \mathrm{Se}, \mathrm{V}$, and Fe; precipitation of (bio)minerals as a result of metabolic processes (e.g. carbonates, oxides, sulphides, etc.) and, finally, influence on mineral composition (leaching of elements), mineral habit and size (inhibited crystal growth), and mineral dissolution.

In addition to the geochemical and morphological characteristics of the potential microbial fossils, other attributes provide critical information for the determination of biogenicity and syngenicity. They include analysis of the habitability of the microenvironmental context and evidence for interaction of the potential fossil microorganisms and their communities with their direct environment. The latter is also important for corroborating the syngenicity of the potential fossil biostructures. For instance, the distribution of interpreted microfossils specifically related to a particle or sediment surface that is subsequently embedded in an early diagenetic mineral matrix would indicate that the microbial structures predated the lithification of the rock.

Finally, investigation of diagenetic to post-diagenetic changes that could have altered potential microbial signatures, introduced younger contamination or produced abiogenic bacteriomorphs, is essential to such a study (Westall, 2008, in press; Westall and Cavalazzi, in press). Abiogenic bacteriomorphs may exhibit one or more of the criteria for biogenicity; for example, minerals such as silica spheres may have sizes and shapes similar to those of microorganisms (e.g. Fig. 6D). However, abiogenic bacteriomorphs show a wider size range distribution and are not associated with EPS (N.B. not all microorganisms produce EPS). Furthermore, abiogenic bacteriomorphs do not exhibit specific cell surface textures, such as a meniscus between dividing cells (the bacteriomorphs may have contiguous and compromised boundaries, but no meniscus, Figs. 6C, D) or deflation and hollowing typical of a dead cell that has lysed and lost part or all of its cell contents (Fig. 6B).

Establishment of biogenicity and syngenicity is therefore based on a suite of biosignatures analysed using a wide variety of techniques that, together, are able to eliminate the possibility of artefact formation and/or contamination.

\section{Results}

\subsection{Mineralogical context}

As noted above, the volcaniclastic sediments at Kitty's Gap (Figs. 3A, C) have been significantly silicified, as indicated by the Raman map of silica in Fig. 3B showing that the finer grained layers are more silicified than the coarser grained ones. The coarser layers are richer in volcanic (felsic) protoliths pseudomorphed by hydromuscovite and, often completely coated with the Ti oxide anatase (Figs. 3C-H). Another Ti oxide, rutile, occurs as a minor component of the protoliths. A translucent layer in the lower part of the hand specimen (arrow Fig. 2B) is almost pure quartz. This layer represents a sheet crack filled by chert (now quartz) during diagenesis when the sediment was already lithified. The hydrothermal fluids rich in silica originated from a nearby hydrothermal vein ( $<2 \mathrm{~m}$ distant).

\subsection{Biosignatures in the 3.446 Ga-old Kitty's Gap Chert}

The Kitty's Gap Chert contains a variety of morphological and chemical biosignatures. Carbon-rich coccoidal, filamentous, chainlike, rod-shaped, and filmy structures resembling microorganisms and their EPS occur in the different layers of the hand specimen and will be described below in the context of specific micro-habitats. Bulk analyses of the different layers were made for carbon content and carbon isotope ratios. Bulk carbon concentrations range from 0.01 to 0.02 wt\% with a peak up to $0.05 \%$, while the enrichment in the ${ }^{13} \mathrm{C}$ isotope ranges from $-25.9 \%$ to $-27.8 \%$ (Westall et al., 2006a). The bulk $\delta^{15} \mathrm{~N}$ value for a $1 \mathrm{~mm}$ thick layer of the sediment is $+3.3 \%$. Most of the nitrogen from the samples was released at higher temperature and seems not to be related to the any significant amounts of carbon in the sample. It could come from mica in which, as it is known, $\mathrm{NH}_{4}^{+}$replaces $\mathrm{K}^{+}$(e.g. Boyd and Philippot, 1998). The relatively high $\mathrm{C} / \mathrm{N}$ ratio $(>50)$ in the samples could imply that most of original organic nitrogen in the microfossils has been lost during metamorphism.

As reported in Westall et al. (2006a), HR-TEM of the isolated carbon fraction documented a slightly ordered, polyaromatic crystal structure typical of mature kerogen (Rouzaud and Clinard, 2002).

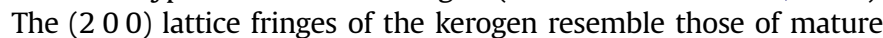
kerogens formed from biological precursor materials (Oberlin, 1989; Skrzypczak-Bonduelle et al., 2008). Our in situ Raman analyses confirm the maturity of the carbon: $D$ and $G$ peaks occur at 1346 and $1586 \mathrm{~nm}$, respectively, and the $D / G$ peak height ratio is 2.5 (Fig. $4 \mathrm{H}$ ). The maturity of the carbon is consistent with the low-grade metamorphic history of the rock (uppermost prehnite-pumpellyite grade, H. Kisch, pers. comm., 2000).

\subsubsection{Volcanic habitats}

3.2.1.1. Volcanic particle surfaces. Optical observation of thin sections of the chert coupled with Raman imaging and spectrometry show two types of carbonaceous phases associated with the surfaces of the volcanic clasts: (1) diffuse clouds (Figs. 4-6) interpreted as microbial colonies (see Section 4 and Westall et al., 2006a) and (2) longitudinal, tunnel-like structures that are probably microbial corrosion features (Fig. 7; Foucher et al., 2010).

In thin section, the diffuse clouds consist of irregularly shaped, diaphanous, brownish coloured matter, identified as disordered carbonaceous matter by Raman spectrometry (Fig. 4). Three dimensional stacking of optical micrographs made at different focal planes show that, although irregular, the diffuse clouds exhibit a more or less planar distribution following the topography of the underlying particle (Fig. 4C). This distribution is not related to any crack in the chert and the clouds are clearly an integral part of the silicified sediment. These observations demonstrate that the diffuse clouds are syngenetic with sediment formation and are not due to later contamination.

Observed at high-resolution by SEM investigation in an HFetched preparation, the edges of the volcanic clasts are invariably associated with carbonaceous matter occurring as fine threads, some tens of $\mathrm{nm}$ thick, and diaphanous, alveolar films (Fig. 5B). The cloud-like organic aggregates on the surfaces of the volcanic clasts appear as accumulations of $<1 \mu \mathrm{m}$-sized, bead-like structures (Figs. 5C and 6A-C). They are interpreted as fossilised colonies of coccoidal microorganisms (see Section 4 and Westall et al., 2006a). The colonies range in size from a few tens of micrometers to hundreds of micrometers and may contain up to many hundreds of individuals. EDX spot analysis and carbon 

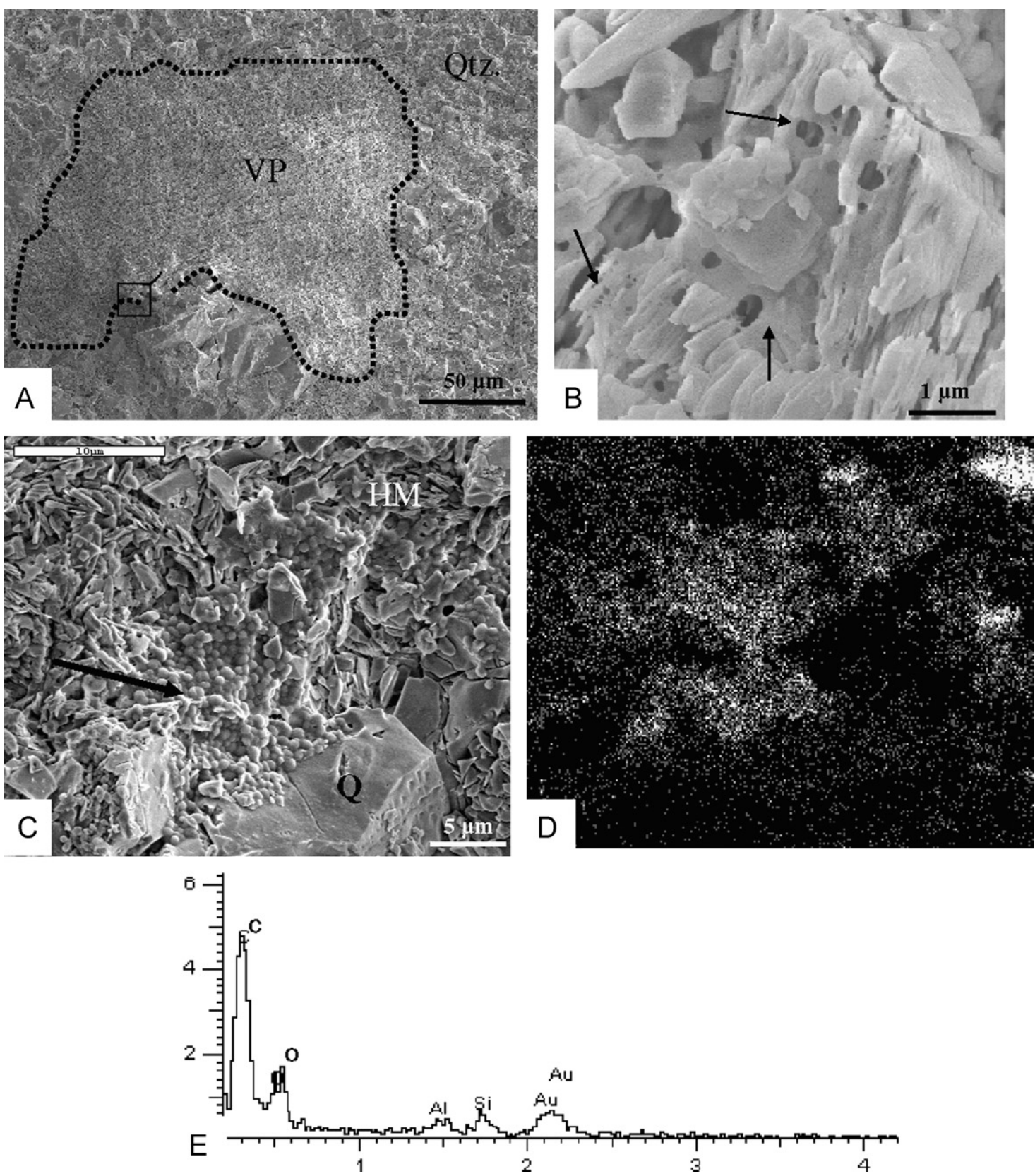

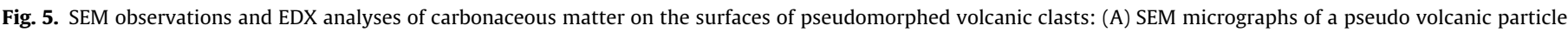

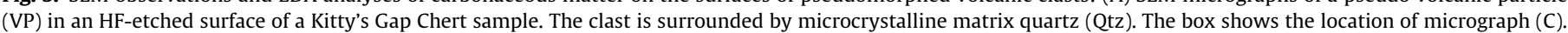

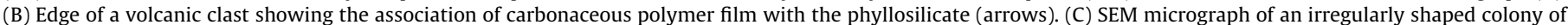

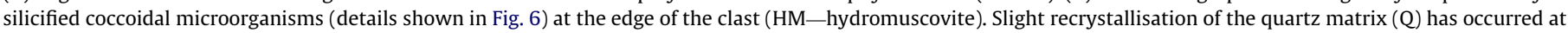
the lower edge of the colony. (D) EDX map of the carbon in the coccoidal colony in (C). (E) EDX spot measurement of the coccoidal colony in (C).

mapping show that they consist of carbon and that there is no associated carbonate (Figs. 5D, E). According to statistical sizeshape analysis of $>2000$ individual bacteriomoprh structures throughout the whole sample, the coccoids fall into two restricted size ranges, 0.4-0.5 and 0.7-0.8 $\mu \mathrm{m}$ (Figs. 6A, B) (Westall et al., 2006a). Many of the coccoids exhibit compromised boundaries resembling cell division and, in some cases, a distinct meniscus between the two parts of the dividing cell may also be visible (Fig. 6C). In one case, one side of the dividing pairs is inflated whereas the other side is deflated (Fig. 6B). A very delicate filmy veil generally coats the individual coccoids resulting in a texture that, at a nanometer-scale level, is wrinkled (Figs. 6B, C).

A second type of carbonaceous structure associated with the volcanic particles consists of tunnel-shaped features that appear black in optical microscopy (Fig. 7; Foucher et al., 2010). The ends of the tunnels are contiguous with the edges of the clasts and they penetrate towards the interior of the clasts. The tunnels are filled with irregular or filmy masses of carbonaceous matter (Figs. 7C, D). Given their carbonaceous composition and association with the edges of the volcanic clasts, we hypothesise that these tunnels were excavated by the corrosion of organic acids produced by colonies of microorganisms on the surfaces of the volcanic particles, such as those in Fig. 6. The carbonaceous matter would then represent EPS and the remains of degraded microbial matter. Such phenomena have been previously described in Early Archaean pillow lava surfaces (Furnes et al., 2004) and also in the surfaces of Early Archaean volcanic clasts (McLoughlin et al., 2007). 

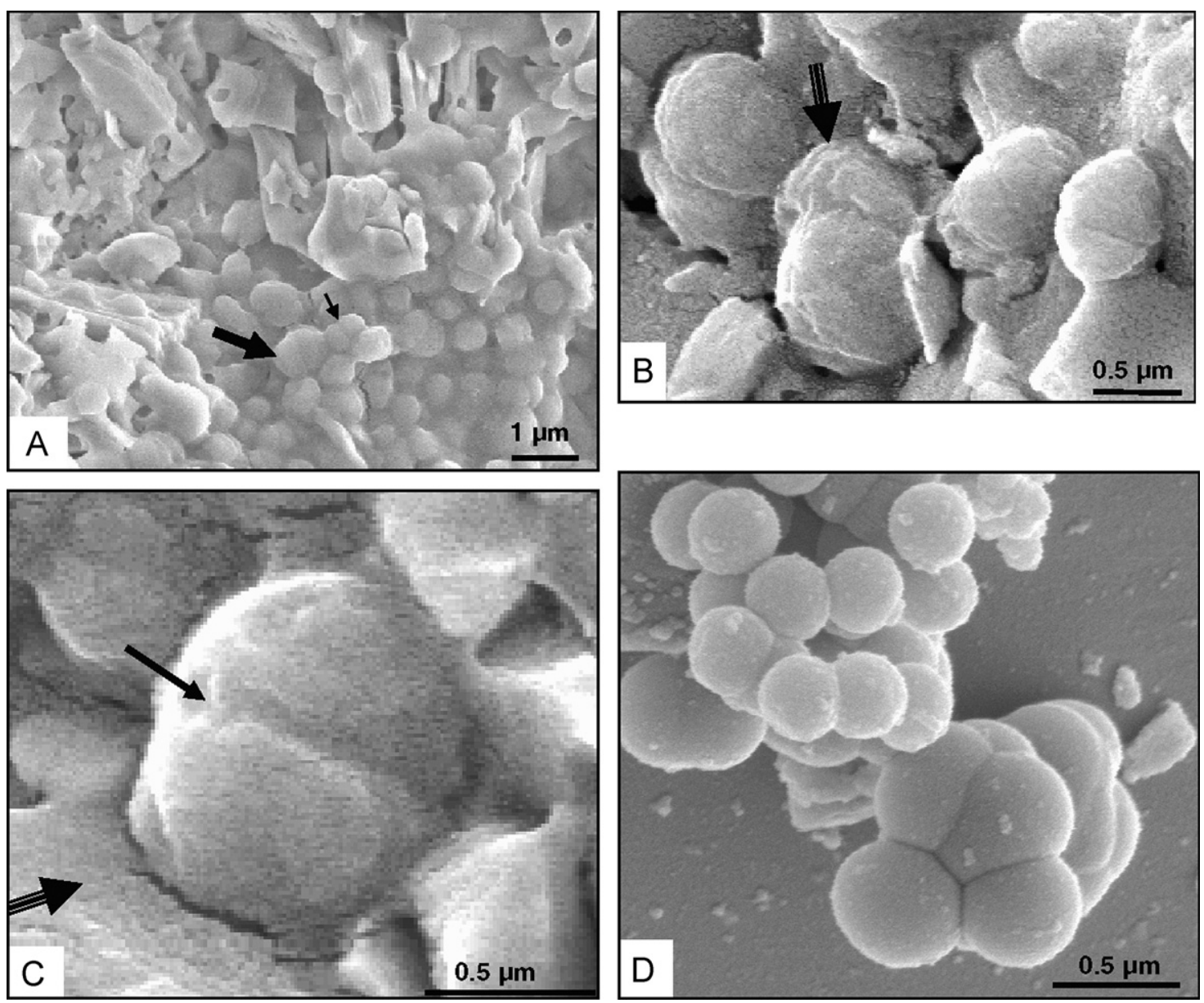

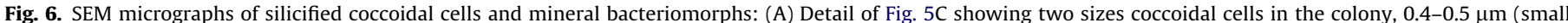

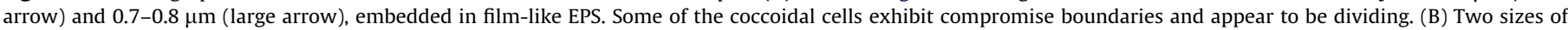

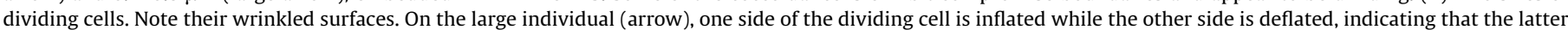

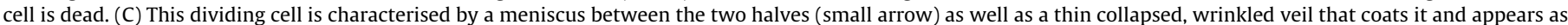

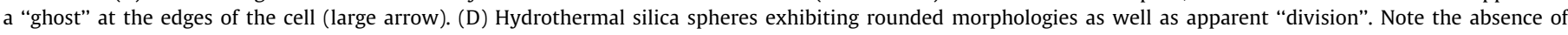
wrinkles on their surfaces and of associated polymer.

Angular pumice fragments, $0.5-1 \mathrm{~cm}$ in size, are embedded in the indurated sediment surface (layer 2 ) that represents a horizon that formed when there was a cessation in sedimentation and was possibly briefly subaerially exposured (Figs. 2B and 9A, B) (Westall et al., 2006a). Diffuse carbonaceous clouds occur within the sericite-filled pores of the pumice. HR-SEM shows both coccoidal and filamentous carbonaceous bacteriomorphs structures within the pores (Westall et al., 2006a, Fig. 10C).

3.2.1.2. Pore space in fine-grained volcanic dust. The lowermost part of layer 3 consists of a black layer immediately overlying the indurated sediment surface, layer 2, in Fig. 2B. It is very finegrained and has a distinct brown colour in thin section (Fig. 9A). Owing to the extremely fine-grain size (silt-clay size) and the pervasive brown colour, it is difficult to distinguish particular structures, such as diffuse clouds of carbonaceous matter, in thin section. Nevertheless, HR-SEM investigation shows that this layer contains fossilised colonies of coccoidal microorganisms, similar to those described above (Figs. 5 and 6). However, the degree of preservation of the colonies of coccoidal microorganisms is lower than those observed on the surfaces of the pseudo volcanic clasts (compare Fig. 8D with Figs. 6A-C). This layer also contains numerous diffuse accumulations of generic carbonaceous polymer that commonly coat and embed mineral particles (Figs. 8A-C).
The alveolar texture of the polymer resembles that of degraded biogenic matter in recent and ancient microbial sediments (Défarge et al., 1996; Westall et al., 2006b).

\subsubsection{Sediment surface habitat}

Layer 2 containing embedded pseudo pumice fragments forms a distinct structure at all levels of observation from macroscopic (Fig. 2) to microscopic (Figs. 9A, B). It may have been subaerially exposed, as indicated by the differential degree of silicification between this layer, including lower part of the pumice fragments, and the immediately overlying sediments (Fig. 9B). This suggests that the layer was subjected to protracted exposure to silica saturated pore waters. This phenomenon is not seen in the Raman mapping of the indurated horizon because the mapping was made on another sample where the horizon has been disturbed and cut out by a fracture. However, the combined sedimentological, textural and geochemical evidence suggest that this horizon represents a brief period of non-sedimentation followed by renewed sedimentation in a quiet hydrodynamic environment.

The top of the indurated sediment layer is characterised by a fine wispy brownish film that conformably follows the contours of the underlying sediment, including the pumice fragments. HRSEM shows that this layer consists of a heterogeneous mixture of carbonaceous components, interpreted as a biofilm (see Section 4 

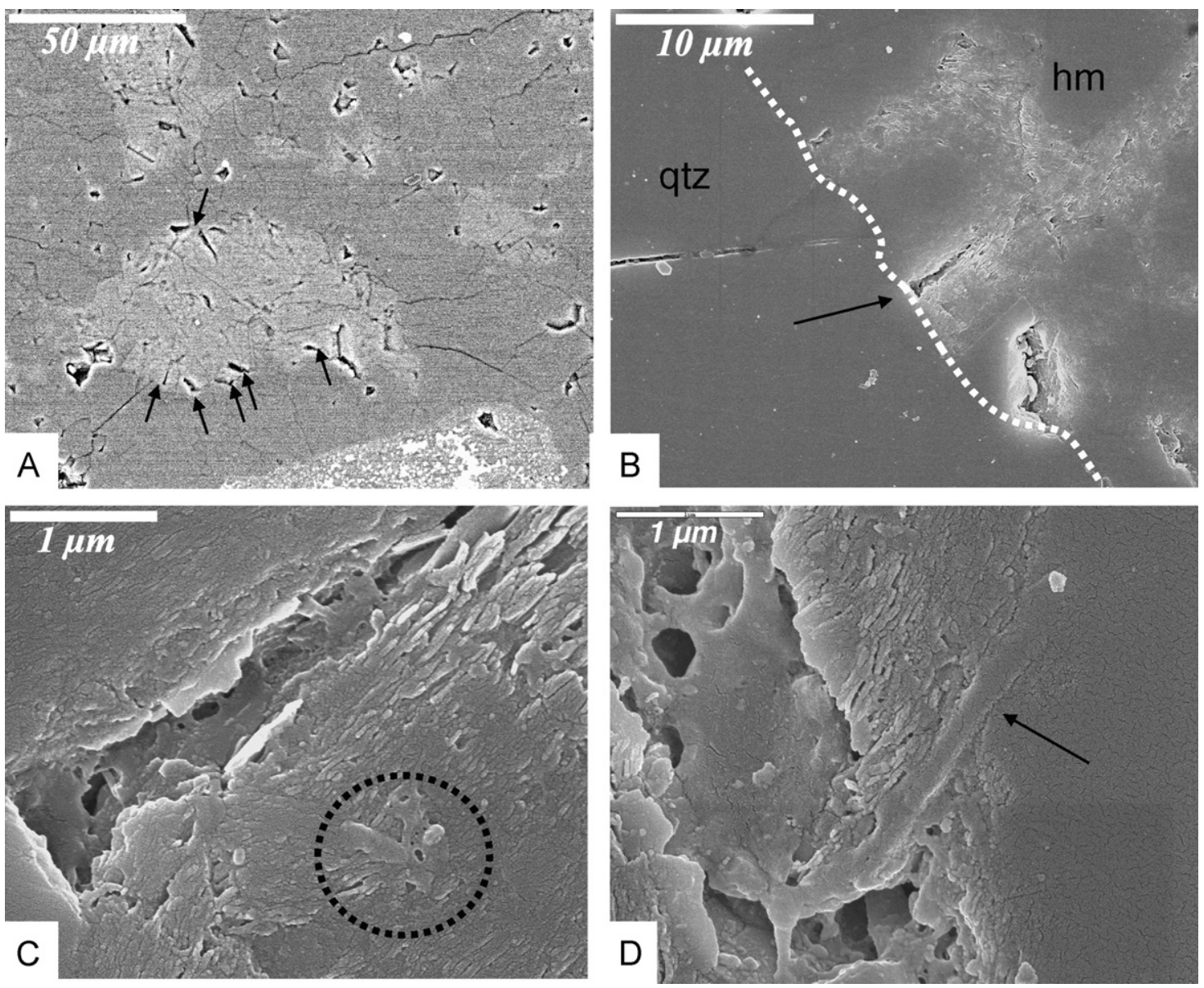

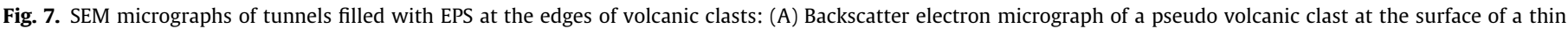

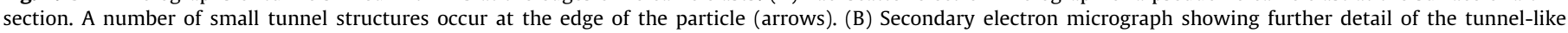

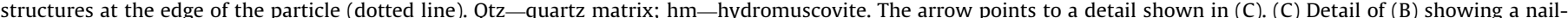

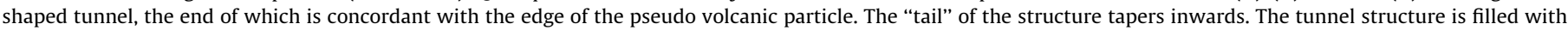

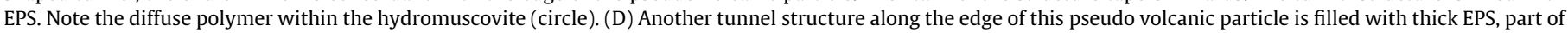
which forms a filamentous structure that disappears into the matrix (arrow).

and Westall et al., 2006a) that include the following:

(1) A fine film exhibiting a partially alveolar texture that coats all particles (Fig. 9A).

(2) Fragments of filamentous structures, $0.25-0.5 \mu \mathrm{m}$ in diameter, that have a striated surface texture and are often partially deflated (Figs. 9A, 10).

(3) Coccoidal structures showing cell division, wrinkled surfaces and deflated features (Fig. 9C) similar to those in Figs. 6A-C. The coccoids also occur in chain formation in varying stages of preservation (Westall et al., 2006a, Fig. 10A).

(4) Rare rod-shaped structures that are contiguously attached to each other at their apices (Fig. 9C, Westall et al., 2006a, Fig. 10F).

(5) Relatively large, rounded or angular detrital carbonaceous grains to which filamentous strands are sometimes attached (Figs. 10D, F), similar to the fragments observed in Fig. 10A. Carbon isotope ratios for this layer, made on a 1-2 mm-thick slice (the layer is $\sim 2 \mathrm{~mm}$ thick here) are $-27.8 \%$.

\section{Discussion}

\subsection{Biogenicity}

The totality of morphological characteristics, the carbonaceous composition, and isotopic signatures, indicate that the structures described here are most likely of biogenic origin. The coccoids, filaments and rods exhibit limited size range; evidence of cell division and the presence of a meniscus between some of the dividing cells in the case of the coccoids and rods; juxtaposition of deflated and inflated cells; wrinkled or striated surface textures; flexibility in the case of the filaments; association with other structures having similar characteristics in colony-like groups; association with other structures having different but consistent morphological characteristics within the colony-like groups (i.e. different species), and association within a film-like substance (EPS). The presence of both deflated and turgid cells in the same colony indicates that some cells were already dead and had lysed when they were silicified while others were living at the time of silicification. Fig. 6B thus shows the juxtaposition of a living process, cell division, as well as the death of one of the cells after division. The carbonaceous film that is commonly associated with the interpreted coccoidal and filamentous microbial remains has the characteristics of microbial EPS. Cell-bound EPS coats many prokaryotes and may be smooth or wrinkled as in Fig. 6. Non-cell bound EPS is a common constituent of microbial colonies (cf. review in Westall et al., 2000; Flemming et al., 2007).

In the colonies of coccoids, the two distinct size ranges indicate that the colonies were formed by two types of microorganisms. These colonies of fossilised coccoids differ from bacteriomorph minerals, such as silica spheres formed in a hydrothermal 

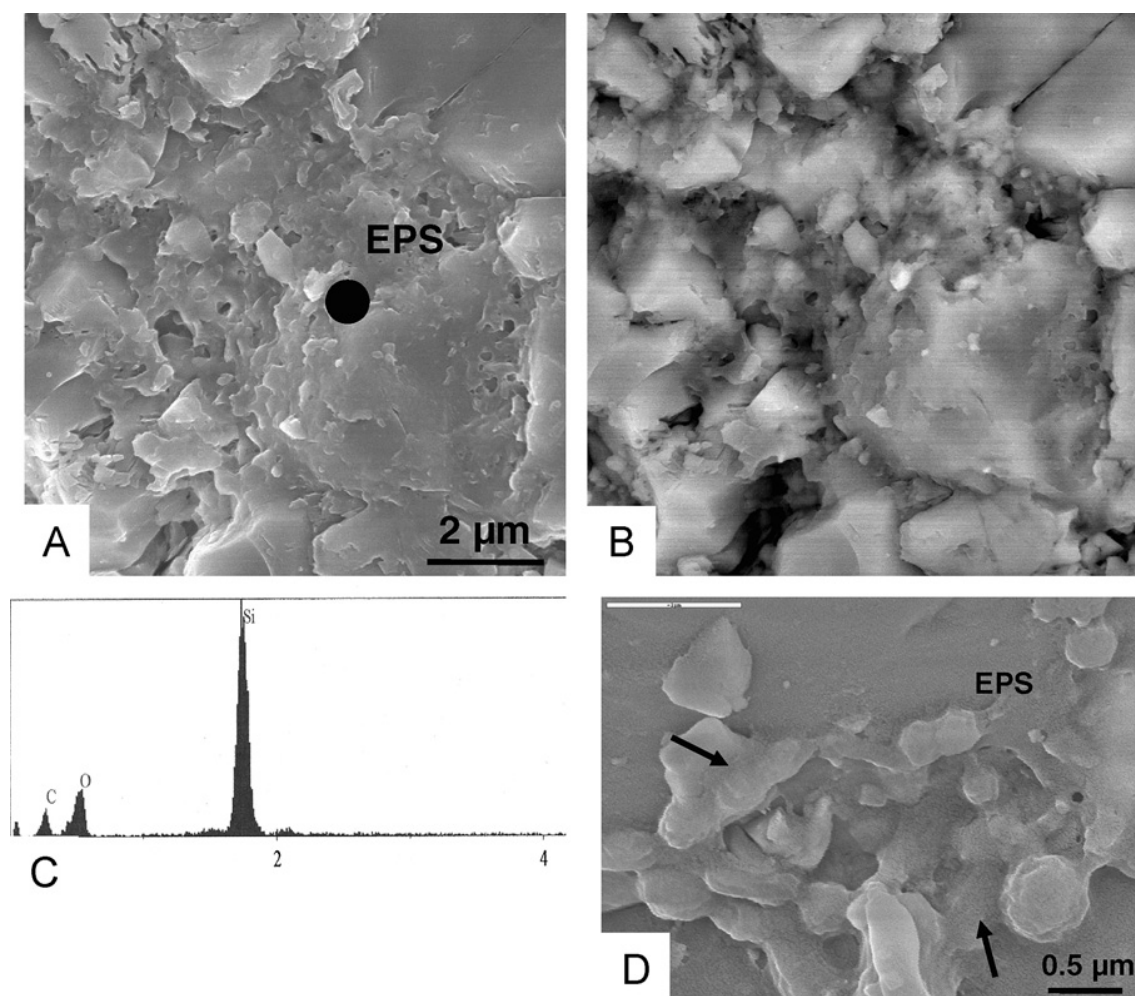

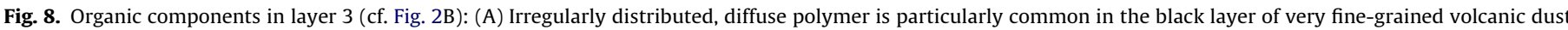

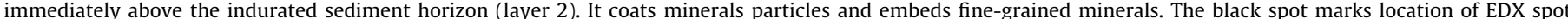

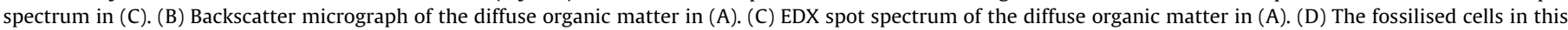

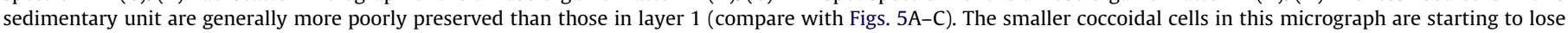
their individual identities (arrows), becoming more amorphous in shape. The larger coccoidal cell (bottom right), is better preserved.

environment (Fig. 6D). Although rounded in shape with compromised boundaries and, in Fig. 6D, apparently exhibiting two size ranges, the crystals in this hydrothermal deposit exhibit a wide range in size, $<0.1-0.5 \mu \mathrm{m}$, are not associated with EPS, have smooth surfaces and are not deflated or hollow. In an abiogenic setting, it could be envisaged that prebiotic carbon molecules in water could precipitate onto surfaces forming a film resembling EPS. However, such a film would not be associated simultaneously with structures that have all the morphological and chemical characteristics of biological cells. We therefore interpret the carbonaceous film as microbial EPS.

The presence of fragments of microbial mats and fragments of deflated filaments in the biofilm on top of layer 2 indicates transport of nearby, possibly photosynthetic microbial mats that were broken up by wave/tidal activity (such phenomena were previously described from similar aged sediments in the Barberton greenstone belt, Tice and Lowe, 2004; Tice, 2009). In modern littoral sediments, microbial biofilms can form on sediment surfaces very rapidly, often between tidal cycles (Stahl, 1994). It is therefore quite possible that such a delicate biofilm could have formed on the re-submerged sediment surface represented by the indurated sediment horizon in Fig. 2. Since this is a very shallow environment of deposition, incorporation of detrital carbonaceous matter (torn-up mat fragments, degraded remnants, etc.) would be common.

\subsection{Syngenicity}

There are a number of lines of evidence that demonstrate that fossilised microbial remains in the Kitty's Gap Chert were present prior to lithification and that the microfossils are therefore intimately associated with the sedimentary environment of deposition. The fact that these structures have been silicified (fossilisation discussed below) does not necessarily mean that they formed at the same time as the sediments. Recent $(<8000$ years old) but fossilised endoliths occur in BIFs and metasediments from the $3.8 \mathrm{Ga}$ Isua greenstone belt (Westall and Folk, 2003). In situ Raman spectrometry of the Kitty's Gap sediment shows that the carbon associated with the coccoidal colonies and EPS-filled tunnels at the surfaces of the volcanic particles is mature and consistent with the age and metamorphic grade of the chert. This is corroborated by the HR-TEM analysis of the carbon and the stepped combustion analysis of the organic carbon of the Kitty's Gap Chert showing that it contains a component that burns above $600^{\circ} \mathrm{C}$, i.e. a mature carbon component (Westall et al., 2006a).

The direct association of microbial colonies with the surfaces of volcanic particles and the formation of a biofilm conformable with the indurated sediment surface indicates that they had to have preceded lithification of the rock. Moreover, filaments identical to those shown in Fig. 10 were observed traversing the boundaries of contiguous recrystallised quartz crystals in the surface of a lightly etched thin section (Westall et al., 2006a, Fig. 7F). Finally, if the microbial structures were a later infiltration, it would be difficult to explain why there are differences in the preservation of the microbial structures with respect to the different layers of sediment in which they occur.

\subsection{Microbial communities in/on the volcanic mudflats of Kitty's Gap}

The strong correlation between the distribution of the microbial cells and a volcanic substrate suggests that the majority 

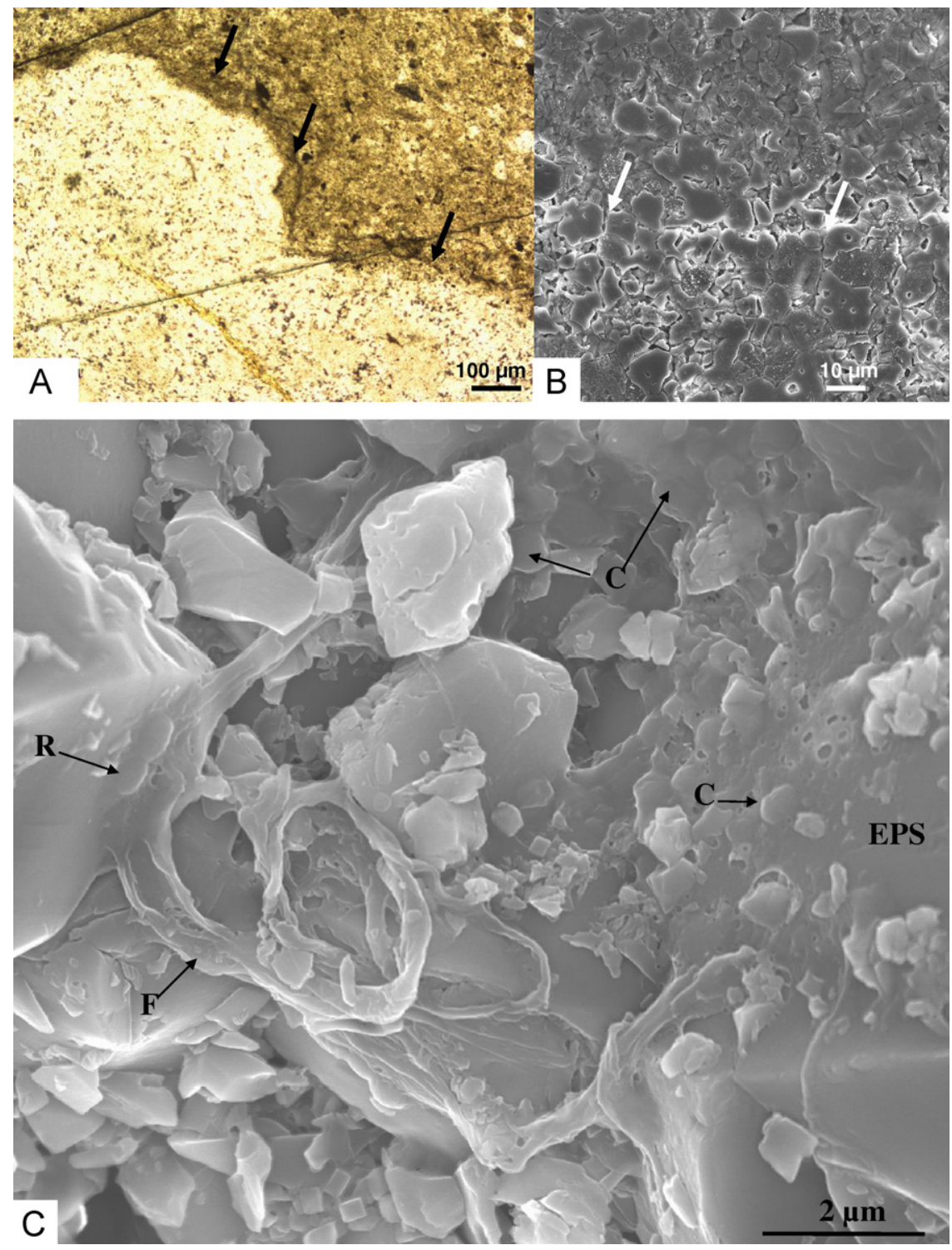

Fig. 9. Layer 2: indurated sediment surface and biofilm: (A) Thin section micrograph showing the indurated layer including a fragment of pumice, overlain by a dark layer of very fine volcanic dust (layer 3). A delicate wavy, brown surface (arrows) overlies this horizon concordantly. (B) Etched thin section showing location of the indurated sediment surface (arrows). (C) Delicate multi-component film formed on the indurated sediment surface in Fig. 2B (cf. Westall and Southam, 2006, Fig. 8). This film consists of a thin layer of alveolar-textured EPS coating particle surfaces (EPS), degraded filaments (F), dividing coccoids (C), and rod-shaped structures (R). Note the submicron size of many of the mineral particles embedded in the film.

of the microorganisms living in the sediments of Kitty's Gap were chemotrophs, i.e. organisms obtaining their energy from inorganic or organic sources. The carbon would have come from dissolved $\mathrm{CO}_{3}^{2}$-in the seawater and the energy from redox reactions at the surface of the volcanic substrate that would liberate $\mathrm{H}^{+}$(chemolithotrophs) or from the degradation of organic matter, such as dead colonies (chemoorganotrophs).

Westall et al. (2006a) speculated that the conformable biofilm on top of the indurated sediment surface could have been formed by a consortium including photosynthetic filamentous microorganisms. However, the fragmented nature of the filaments, together with resedimented carbonaceous filamentous clasts, suggests rather that these components were washed into the depositional environment from a nearby source, possibly from wave-torn photosynthetic microbial mats.

\subsection{Fossilisation of the microbial structures}

Microbial cells tend to degrade rapidly, unless their cell surfaces are stabilised by the chelation of metals ions such as Fe (Ferris et al., 1986). Fossilisation is therefore a rapid process, as has been experimentally demonstrated (Benning et al., 2004; Orange et al., 2009; Toporski et al., 2002; Westall et al., 1995). The Early Archaean seawater was saturated with respect to amorphous silica (Siever, 1992) and, in the case of the Kitty's Gap environment, there was an additional source of hydrothermal silica (van den Boorn et al., 2007). Furthermore, diagenetic devitrification of the volcanic particles in the sediments would have caused high silica concentrations in the pore waters. The microorganisms inhabiting the Kitty's Gap sediments were thus silicified. However, differential preservation of the microbial cells in different horizons of the sediment, for example, between layers 1 and 3, indicates that the concentration of 

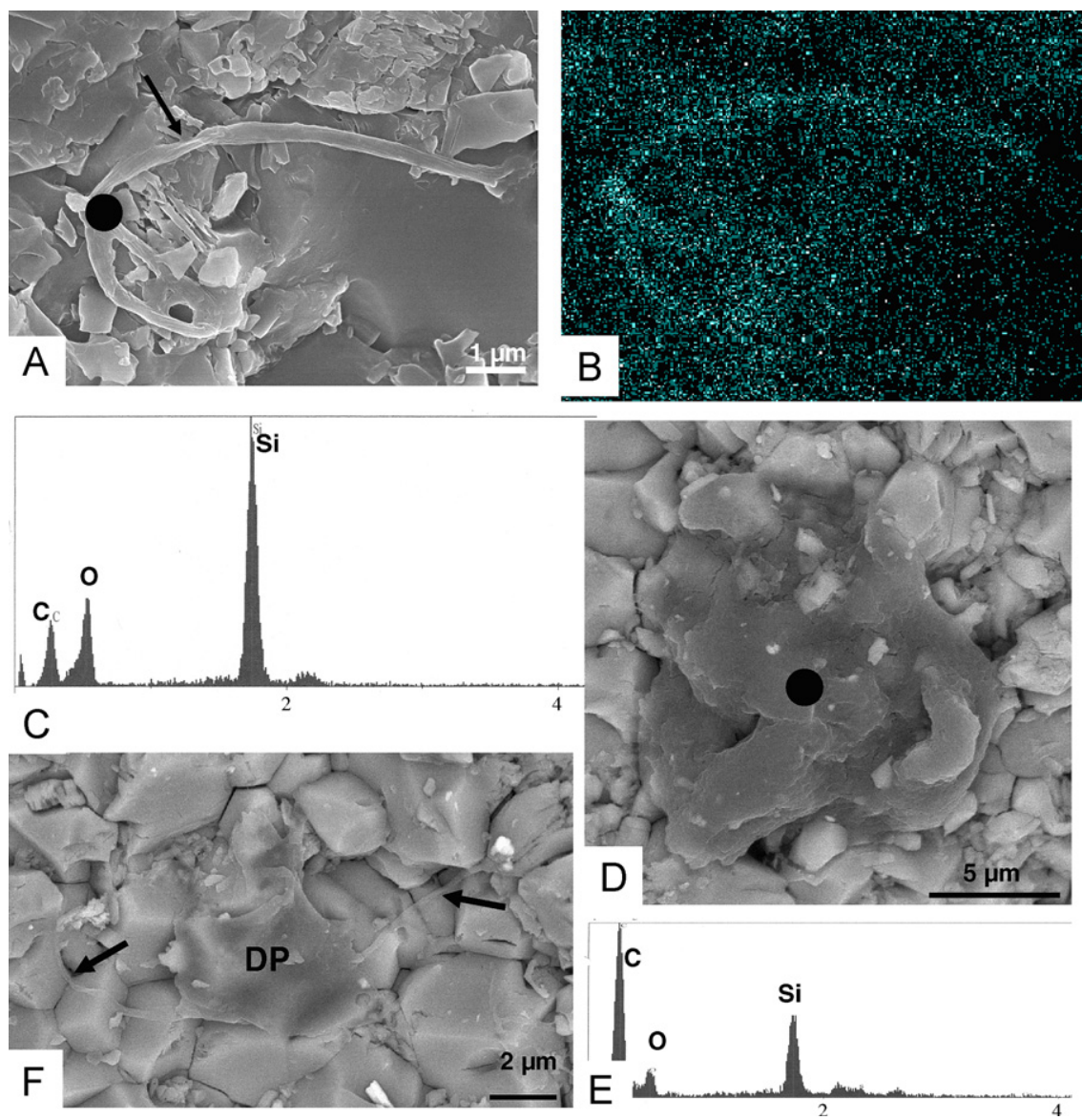

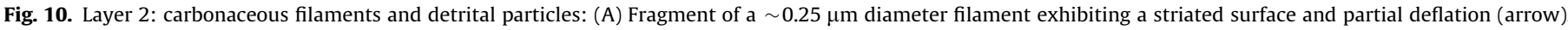

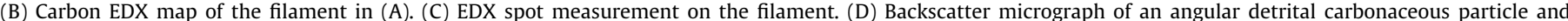
corresponding EDX spot analysis (E). (F) Detrital carbonaceous particle (DP) with attached filaments (arrows) similar to the filament in (A).

silica in the seawater/pore waters varied with time. This observation concurs with the geochemical evidence for pulses of hydrothermal activity and silica input into the seawater (van den Borrn et al., 2007; van den Boorn, 2008).

\subsection{Post-depositional history of the Kitty's Gap sediments}

Post depositional diagenetic processes concerned devitrification of the volcanic protoliths and their replacement by hydromuscovite (Orberger et al., 2006; Rouchon et al., 2005) and cementation by silica. Silicon isotope data indicate hydrothermal temperatures less than $200{ }^{\circ} \mathrm{C}$ (van den Boorn et al., 2007; van den Boorn, 2008). After diagenesis, the Kitty's Gap Chert was then subjected to low grade regional metamorphism (prehnitepumpellyite facies, H. Kisch, pers. comm., 2000), probably prior to $3.2 \mathrm{Ga}$ (Wijbrans and McDougall, 1987).

\section{Conclusions}

The Kitty's Gap Chert is a silicified volcanic sediment deposited in a littoral mudflat environment. The muddy sediments presented predominantly volcanic habitats, as well as a stabilised, indurated sediment surface. They hosted a small variety of microorganisms, mostly coccoidal, and some filamentous and rare rod shapes, characterised by their small size. Colonies of coccoidal microorganisms having two size modes, $0.4-0.5$ and $0.7-0.8 \mu \mathrm{m}$, developed on the surfaces of the volcanic clasts and scoriaceous pumice, as well as within a layer of fine-grained (silt-size or less) volcanic dust. The filaments are $\sim 0.25 \mu \mathrm{m}$ in diameter and up to tens of micrometers in length. They occur most commonly as degraded fragments and sometimes as portions of torn filamentous mats that were transported from a nearby source. The rare rod-shaped microorganisms are $\leq 1 \mu \mathrm{m}$ in length and occur in a biofilm that formed on an indurated, stabilised sediment surface. Although individually small in size, the fossilised microbial structures described from the Kitty's Gap Chert form colonies or biofilms that are optically visible in rock thin sections. However, a range of sophisticated techniques including high resolution scanning and transmission electron microscopy, Raman and EDX analyses, and stable carbon isotope analyses were critical in establishing the biogenicity of the structures. The fossil biota was probably dominated by microorganisms using chemo-organo or lithotrophic metabolisms, although possible remains of photosynthetic mats also occur in the sediments.

The 3.446 Ga Kitty's Gap Chert is a particularly relevant example in terms of the search for life on Mars. The volcaniclastic sediments were deposited in a shallow water aqueous environmental setting that would have been relatively common in the Noachian period of Mars. Indeed, the Kitty's Gap sediments ( $3.446 \mathrm{Ga}$ ) postdate the Noachian period (end $3.7 \mathrm{Ga}$ ) by only a few hundred million years. The simple fossilised life forms that they contain could therefore hypothetically reflect the kinds of simple life that may have occurred on Noachian Mars, if life ever appeared on that planet. This implies, however, small microorganisms, low bulk carbon contents, and cryptic biosignatures. Given the necessity of using a multidisciplinary array of sophis- 
ticated techniques to establish the biogenicity of such microfossils, it may not be possible to unambiguously establish biogenicity of early Martian life using the kinds of in situ instrumentation presently envisaged for upcoming missions. We therefore recommend returning specifically chosen Martian samples to Earth for detailed analysis in terrestrial laboratories.

\section{Acknowledgment}

J.M. Bény is thanked for his aid with some of the in situ Raman spectral analyses.

\section{References}

Benning, L.G., Phoenix, V.R., Yee, N., Konhauser, K.O., 2004. The dynamics of cyanobacterial silicification: an infrared micro-spectroscopic investigation. Geochim. Cosmochim. Acta 68, 743-757.

Bibring, J.P., Langevin, Y., Mustard, et al., 2006. Global mineralogical and aqueous Mars history derived from OMEGA/Mars Express data. Science 312, 400-404.

Bishop, J.L., Dobrea, E.Z.N., McKeown, et al., 2008. Phyllosilicate diversity and past aqueous activity revealed at Mawrth Vallis, Mars. Science 321, 830-833.

Boyd, S.R., Philippot, P., 1998. Precambrian ammonium biogeochemistry: a study of the Moine metasediments, Scotland. Chem. Geol. 144, 257-268.

Brack, A., 2002. Water, the spring of life. In: Horneck, G., Baumstark-Kahn, C. (Eds.), Astrobiology. Springer-Verlag, Berlin, pp. 79-88.

Buick, R., 1990. Microfossil recognition in Archean rocks: an appraisal of spheroids and filaments from a 3500 m.y. old chert-barite unit at North Pole, Western Australia. Palaios 5, 441-459.

Carr, M., 2006. The Surface of Mars.. Cambridge Planetary Science, Cambridge 306 pp.

Carr, M.H., Head III, J.W., 2010. Geologic history of Mars. Earth Planet. Sci. Lett. 294, 185-203.

Cabrol, N., Grin, E., 1999. Distribution, classification, and ages of martian impact lakes. Icarus 142, 160-172.

Cady, S.L., Farmer, J.D., Grotzinger, J.P., et al., 2003. Morphological biosignatures and the search for life on Mars. Astrobiology 3, 351-368.

Cronin, J.R., Chang, S., 1993. Organic matter in meteorites: molecular and isotopic analyses of the Murchison meteorites. In: Green berg, J.M., Mendoza-Gomez, C.X., Pirronello, V. (Eds.), The Chemistry of Life's Origins.. Kluwer, Dordrecht, pp. 209-258.

Défarge, C., Trichet, J., Jaunet, A.M., 1996. Texture of microbial sediments revealed by cryo-scanning electron microscopy. J. Sediment. Res. 66, 935-947.

de Vries, S.T., 2004. Early Archaean sedimentary basins: depositional environment and hydrothermal systems. Geol. Ultraiectina 244, 1-160.

de Vries, S.T., Nijman, W., Wijbrans, J.R., et al., 2006. Stratigraphic continuity and early deformation of the central part of the Coppin Gap Greenstone Belt Pilbara, Western Australia. Precambrian Res. 147, 1-27.

Duprat, J., Dobrică, E., Engrand, C., et al., 2010. Extreme deuterium excesses in ultracarbonaceous micrometeorites from central Antarctic snow. Science 328, $742-745$.

Ferris, F.G., Beveridge, T.J., Fyfe, W.S., 1986. Iron-silica crystallite nucleation by bacteria in a geothermal sediment. Nature 320,609-611.

Flemming, H.-C., Neu, T.R., Wozniak, D.J., 2007. The EPS matrix: the "House of Biofilm Cells". J. Bacteriol. 189 (22), 7945-7947.

Foucher, F., Westall, F., Brandstatter, et al., 2010. Testing the survival of microfossils in artificial martian sedimentary meteorites during entry into Earth's atmosphere: the STONE 6 experiment. Icarus 207, 616-630.

Furnes, H., Banerjee, N.R., Muehlenbachs, K., et al., 2004. Early life recorded in Archean pillow lavas. Science 304, 578-581.

Heisinger, H., Head, J.W., 2002. Topography and morphology of the Argyre Basin, Mars: implications for its geologic and hydrologic history. Planet. Space Sci. 50, 939-981.

Hofmann, A., Bohlar, R., 2007. Carbonaceous cherts in the Barberton Greenstone Belt and their significance for the study of early life in the Archean record. Astrobiology 7, 355-388.

Holm, N., Andersson, E.M., 1998. Hydrothermal systems. In: Brack, A. (Ed.), The Molecular Origins of Life. Cambridge University Press, Cambridge, pp. 86-99.

Jakosky, B., Phillips, R., 2001. Mars' volatile and climate history. Nature 412 237-244.

Jakosky, B., Westall, F., Brack, A., 2007. Mars. In: Sullivan, W., Baross, J. (Eds.), Planets and Life: The Emerging Science of Astrobiology. Cambridge University Press, Cambridge, pp. 357-387.

Kasting, J.F., Ono, S., 2006. Paleoclimates: the first two billion years. Philos. Trans. R. Soc. London B 361, 917-929.

Martin, W., Russell, M.J., 2007. On the origin of biochemistry at an alkaline hydrothermal vent. Philos. Trans. R. Soc. London B 367, 1187-1925.

McKay, C.P., Stoker, C.R., 1989. The early environment and its evolution on Mars: implication for life. Rev. Geophys. 27, 189-214.

McLoughlin, N., Brasier, M.D., Wacey, D., et al., 2007. On biogenicity criteria for endolithic microborings on early earth and beyond. Astrobiology 7, 10-26.
Mullie, F., Reisse, J., 1987. Organic matter in carbonaceous meteorites. Top. Curr. Chem. 139, 83-117.

Nisbet, E., Zahnle, K., Gerasimov, et al., 2007. Creating Habitable Zones, at all Scales, from Planets to Mud Micro-Habitats, on Earth and on Mars. Space Sci. Rev. 129, 79-121.

Oberlin, A., 1989. High-resolution TEM studies of carbonization and graphitization. In: Thrower, P.A. (Ed.), Chemistry and Physics of Carbon, 22. Marcel Dekker, New York, pp. 1-143.

Orange, F., Westall, F., Disnar, J.-R., et al., 2009. Experimental silicification of the extremophilic Archaea Pyroccus abyssi and Methanocaldococcus jannaschii. Applications in the search for evidence of life in early Earth and extraterrestrial rocks. Geobiology 7, 403-418.

Orberger, B., Rouchon, V., Westall, F., De Vries, ST., Wagner, C., Pinti, D.L., 2006. Protoliths and micro-environments of some Archean Cherts. In: Reimold, W.U., Gibson R. (Eds.), Processes on the Early Earth, vol. 405. pp. 133-152.

Perron, J.T., Mitrovica, J.X., Manga, M., et al., 2007. Evidence for an ancient Martian ocean in the topography of deformed shorelines. Nature 447, 840-843.

Rouchon, V., Pinti, D.L., Gallien, J.P., et al., 2005. NRA analyses of N and C in hydromuscovite aggregates from a $3.5 \mathrm{Ga}$ chert from Kittys Gap, Pilbara, Australia. Nucl. Intrum. Methods Phys. Res. B 231, 536-540.

Rouzaud, J.N., Clinard, C., 2002. Quantitative high resolution transmission electron microscopy: a promising tool for carbon materials characterization. Fuel Process. Technol. 77-78, 229-235.

Ruiz, J., Fairén, A.G., Dohm, J.M., et al., 2004. Thermal isostasy and deformation of possible paleoshorelines on Mars. Planet. Space Sci. 52, 1297-1301.

Schopf, J.W., 1993. Microfossils of the Early Archean Apex Chert: new evidence of the antiquity of life. Science 260, 640-646.

Schrenk, M.O., Kelley, D.S., Delaney, J.R., et al., 2003. Incidence and diversity of microorganisms within the walls of an active deep-sea sulfide chimney. Appl. Environ. Microbiol. 69, 3580-3592.

Siever, R., 1992. The silica cycle in the Precambrian. Geochim. Cosmochim. Acta 56, 3265-3272.

Skrzypczak-Bonduelle, A., Binet, L., Delproux, O., et al., 2008. EPR of radicals in primitive organic matter: a tool for the search for biosignatures or the most ancient traces of life. Appl. Magn. Reson. 33, 371-439.

Southam, G., Westall, F., 2007a. Geology, life and habitability. In: Spohn, T. (Ed.), Treatise on Geophysics-Planets and Moons, vol. 10. Elsevier, Amsterdam, pp. 421-438.

Southam, G., Rothschilde, L., Westall, F., 2007b. The geology and habitability of terrestrial planets: fundamental requirements for life. Geology and habitability of terrestrial planets. Space Sci. Rev. 129, 7-34.

Spohn, T., 1991. Mantle differentiation and thermal evolution of Mars, Mercury, and Venus. Icarus 90, 222-236.

Stahl, L.J., 1994. Microbial mats: ecophysiological interactions related to biogenic sediment stabilization. In: Krumbein, W.E., Paterson, D.M., Stahl, L.J. (Eds.), Biostabilization of Sediments. Biblioteks und Informationssystem der Carl von Ossietzky Universität, Oldenburg, pp. 41-54

Tice, M., Lowe, D.R., 2004. Photosynthetic microbial mats in the 3416-Myr-old ocean. Nature 431, 549-552.

Tice, M., 2009. Environmental controls on photosynthetic microbial mat distribution and morphogenesis on a 3.42 Ga clastic-starved platform. Astrobiology 9 , 989-1000.

Toporski, J.K.W., Westall, F., Thomas-Keprta, K.A., et al., 2002. The simulated silicification of bacteria-new clues to the modes and timing of bacterial preservation and implications for the search for extraterrestrial microfossils. Astrobiology 2, 1-26.

Van den Boorn, S.H.J.M., 2008. Silicon isotopes and the origin of Archaean cherts. Unpublished Ph.D. Dissertation, University of Utrecht.

Van den Boorn, S.H.J.M., Van Bergen, M.J., Nijman, W., Vroon, P.Z., 2007. Dual role of seawater and hydrothermal fluids in Early Archean chert formation: evidence from silicon isotopes. Geology 35, 939-942.

Verchovsky, A.B., Fisenko, A.V., Semjonova, L.F., Pillinger, C.T., 1997. Heterogeneous distribution of xenon-HL within presolar diamonds. Met. Planet. Sci. 32, A131-A132.

Verchovsky, A.B., Sephton, M.A., Wright, I.P., et al., 2002. Separation of planetary noble gas carrier from bulk carbon in enstatite chondrites during stepped combustion. Earth Planet. Sci. Lett. 199, 243-255.

Westall, F., 1999. The nature of fossil bacteria: a guide to the search for extraterrestrial life. J. Geophys. Res. Planets 104, 16,437-16,451.

Westall, F., 2005a. Early life on Earth and analogies to Mars. In: Tokano, T. (Ed.), Water on Mars and Life. Springer, Berlin, pp. 45-64.

Westall, F., 2005b. Life on the early Earth: a sedimentary view. Science 434, 366-367.

Westall, F., 2008. Morphological biosignatures in terrestrial and extraterrestrial materials. Space Sci. Rev. 135, 95-114.

Westall, F., 2009. Life on an anaerobic planet. Science 232, 471-472.

Westall, F., in press. Early life, nature, distribution and evolution. In: Gargaud, M., et al. (Eds.), Origins of Life, An Astrobiology Perspective. Cambridge University Press, pp. 391-413.

Westall, F., Boni, L., Guerzoni, M.E., 1995. The experimental silicification of microbes. Palaeontology 38, 495-528.

Westall, F., Steele, A., Toporski, J., et al., 2000. Polymeric substances and biofilms as biomarkers in terrestrial materials: implications for extraterrestrial samples. J. Geophys. Res-Planets 105, 24,511-24,527.

Westall, F., Folk, R.L., 2003. Exogenous carbonaceous microstructures in Early Archaean cherts and BIFs from the Isua greenstone belt: implications for the search for life in ancient rocks. Precambrian Res. 126, 313-330. 
Westall, F., de Vries, S.T., Nijman, W., et al., 2006a. The 3.466 Ga Kitty's Gap Chert, an Early Archaean microbial ecosystem. In: Reimold, W.U., Gibson, R. (Eds.), Processes on the Early Earth (Geological Society of American Special Publications), vol. 405, pp. 105-131.

Westall, F., de Ronde, C.E.J., Southam, G., et al., 2006b. Implications of a 3.472$3.333 \mathrm{Ga}$-old subaerial microbial mat from the Barberton greenstone belt, South Africa for the UV environmental conditions on the early Earth. Philos. Trans. R. Soc. London Ser. B 361, 1857-1875.

Westall, F., Southam, G., 2006. Early life on Earth. In: Benn, K. (Ed.), Archean Geodynamics and Environments, 164. AGU Geophysical Monographs, pp. 283-304.
Westall, F., Cavalazzi, B., in press. Biosignatures in rocks. In: Thiel, V., Reitner, J. (Eds.), Encyclopedia of Geobiology. Springer, Berlin.

Wijbrans, J.R., McDougall, I., 1987. On the metamorphic history of an Archean granitoid greenstone terrane, East Pilbara, Western Australia, using the $40 \mathrm{Ar}$ / 39Ar age spectrum technique. Earth Planet. Sci. Lett. 84, 226-242.

Wright, I.P., Grady, M.M., Pillinger, C.T., 1988. Carbon, oxygen and nitrogen isotopic compositions of possible Martian weathering products in EETA79001. Geochimica et Cosmochimica Acta 52, 917-924.

Wright, I.P., Grady, M.M., Pillinger, C.T., 1989. Organic materials in a Martian meteorite. Nature 340, 220-222. 